requires less power consumption. Based on the calculation result obtained from the fitting equation shown in Figure 9, the optimum length of thin cutter $l$ is $13.07 \mathrm{~mm}$.

The banana crown-cutting tool using combined cutters is a core component of the banana harvest machine. It requires less energy consumption and provides high grade of cut surface quality. Experimental results show that the number of cutter sets, width of the thick cutter and length of the thin cutter have significant impact on cutting quality. Cutting speed, thickness of thick cutter and length of thin cutter have an impact on cutting force and power consumption. The optimum parameters of the cutter sets are as follows: number of cutter sets $n$ is five groups, cutting speed $v$ is $60 \mathrm{~mm} / \mathrm{s}$, cutting edge angle $\theta$ of thick cutter is $16^{\circ}$, thickness $\delta$ and width $d$ of the thick cutter are 2 and $12 \mathrm{~mm}$ respectively, and length of the thin cutter $l$ is $13.07 \mathrm{~mm}$.

1. Li, J., The study on world banana trade pattern and its influence on Chinese banana market. Hainan University, Hainan, China, 2015.

2. Zhu, Z. et al., Parameter optimization and experiment of pneumatic holding part for banana crown cutting. Trans. Chin. Soc. Agric. Eng., 2016, 4, 33-39.

3. FAO, Production/yield quantities of Bananas in the World, Food and Agriculture Organization of the United Nation, Rome, Italy, 2018; http://www.fao.org/faostat/en/\#data/QC/visualize

4. Liu, J., Li, J. and Yang, Z., Review current status of postharvest handling equipment for banana. J. Agric. Mech. Res., 2014, 11, $249-252+257$.

5. Xu, Z., Sun, J. and Zhao, L., Classification, integration of preliminary processing technology in banana producing areas of China. Trans. Chin. Soc. Agric. Eng., 2015, S1, 332-336.

6. Zhou, K. and Yang, J., An elementary introduction to mechanized management of banana. Trop. Agric. Sci. Technol., 2010, 1, 24-25.

7. Yang, Z. et al., Rotary type banana combing machine. Chinese Patent No. CN201310067178.3, China, 2013.

8. Duan, J., Yang, Z. and Zhu, Z., Inserting cutting type variable diameter banana shaft removing and combing cutter self-adaptive to diameter of banana spike rod. Chinese Patent No. CN201310548281A, China, 2013.

9. Duan, J., Zhu, Z. and Yang, Z., Reducing impact insertion-cutting type annular banana comb cutting device. Chinese Patent No. CN201410314515A, China, 2014.

10. Von, H., Bananas, Interscience Publishers, New York, USA, 1950.

11. Li, Y., Qin, T., Chen, J. and Zhao, Z., Experiments and analysis on mechanical property of corn stalk reciprocating cutting. Trans. Chin. Soc. Agric. Eng., 2011, 1, 160-164.

12. Shi, Y., Wang, X., Zhang, Y., Morice, O. O. and Ding, W., Test and analysis on the influence factors of reciprocating cutting force of Artemisia saelengensis harvester. J. Chin. Agric. Mech., 2018, 12, 46-53.

13. Zhang, H., Study on the shear properties and cutting parameters of alfalfa stem. China Agricultural University, Beijing, China, 2015.

14. Wang, H., Wang, F., Yang, Z. and Guo, W., Experimental study on the influencing factors of cutting resistance of sunflower stalk. J. Chin. Agric. Univ., 2018, 5, 102-107.

15. Yang, Z. et al., Longitudinal stability control of orchard cabledriven hanging transport system. Trans. Chin. Soc. Agric. Eng., 2015, 31, 64-70.

16. Li, J. et al., Dynamics of electric pulley conveying cableway system in banana plantation. Trans. Chin. Soc. Agric. Mach., 2013, 1, 211-216.
17. Ding, S., Xue, X., Cai, C., Cui, L. and Chen, C., Optimization and experiment of blade parameter for pear branches cutting device. Trans. Chin. Soc. Agric. Eng., 2015, S2, 75-82.

18. Li, B., Effects of different drying methods on quality of banana products. Food Sci., 2016, 15, 100-106.

19. Fang, S. et al., Influence of spindle rotating speed on machining quality for chips of semiconductor. Chin. Mech. Eng., 2007, 18, 2187-2190.

20. Chen, D., Cheng, L., Li, J. and Wang, X., Analysis simulation on edge angle of fin cutter blade based on finite element method. Tool Eng., 2013, 10, 44-46.

21. Zhou, S., Yang, W., Yang, J., Liang, Z. and Mo, J., Dynamic simulation experiment of one-blade cutting sugarcane process. Trans. Chin. Soc. Agric. Mach., 2011, 1, 68-73.

ACKNOWLEDGEMENTS. This research was supported by the National Natural Science Foundation of China (Grant No. 51675189), the China Agriculture Research System (CARS-31) and the Innovative Research Team of Guangdong Province Agriculture Research System (2017LM2153).

Received 10 April 2019; revised accepted 16 May 2019

doi: $10.18520 / \mathrm{cs} / \mathrm{v} 117 / \mathrm{i} 3 / 492-497$

\section{Estimation of soil properties and leaf nutrients status of oil palm plantations in an intensively cultivated region of India}

\author{
Sanjib Kumar Behera ${ }^{1, *}$, Arvind Kumar Shukla ${ }^{1}$, \\ Kancherla Suresh ${ }^{2}$ and Ravi Kumar Mathur ${ }^{2}$ \\ ${ }^{1}$ ICAR-Indian Institute of Soil Science, Bhopal 462 038, India \\ ${ }^{2}$ ICAR-Indian Institute of Oil Palm Research, West Godavari 534 450, \\ India
}

Oil palm (Elaeis guineensis Jacq.) is cultivated in several countries of the world. The information pertaining to soil properties and status of leaf nutrients in oil palm plantations (OPP) is essential for proper nutrient management to obtain higher yield of the crop. The study, therefore, was undertaken by conducting a survey of OPP in west Godavari district, India and collecting 306 soil samples and 153 leaf samples. Collected samples (soil and leaf) were analysed for different parameters after their processing. The studied soil parameters (soil pH, electrical conductivity, organic carbon, available phosphorous, available potassium, exchangeable calcium, exchangeable magnesium, available sulphur and available boron) in surface $(0$ to $20 \mathrm{~cm})$ and sub-surface $(20$ to $40 \mathrm{~cm})$ soil varied widely. The soil parameters had $C V$ values

*For correspondence. (e-mail: Sanjib.Behera@icar.gov.in) 
from $7.13 \%$ to $80.7 \%$. The concentrations of nitrogen $(\mathrm{N})$, phosphorus (P) and potassium $(\mathrm{K})$ in leaf samples were $0.62-3.97 \%, 0.04-0.26 \%$, and $0.34-1.38 \%$ respectively. Whereas, the concentrations of calcium (Ca), magnesium (Mg), sulphur (S) and boron (B) were $0.66-2.66 \%, \quad 0.10-1.03 \%, \quad 0.02-0.35 \%$ and 9.55 $119 \mathrm{mg} \mathrm{kg}^{-1}$ respectively. The norms and indices of Diagnosis and Recommendation Integrated System (DRIS) were obtained using various nutrient expressions. The leaf nutrient requirement order was $\mathbf{B}>\mathbf{M g}>\mathrm{K}>\mathbf{N}>\mathbf{P}$. The optimum concentrations of leaf nutrients were $1.57-2.63 \%$ for $N, 0.08-0.16 \%$ for $\mathrm{P}, 0.48-0.88 \%$ for $\mathrm{K}, 0.25-0.71 \%$ for $\mathrm{Mg}$ and 22.6 $60.2 \mathrm{mg} \mathrm{kg}^{-1}$ for $B$. Information about soil nutrient status and nutrient requirement order and optimum leaf nutrient ranges can be used for effective management of nutrients in the OPP of the study region.

Keywords: DRIS, leaf nutrient, oil palm, soil property.

THE potential oil yielding capacity of oil palm (Elaeis guineensis Jacq.) is $\approx 19.0 \mathrm{t}$ oil/ha/year, which is the highest among the oil seed crops. Oil palm is cultivated in different countries of the world ${ }^{1}$. Of these, countries like Indonesia and Malaysia lead in palm oil production and export. Understanding the importance of the crop, efforts are being made in India to increase the acreage under oil palm crops to mitigate the vegetable oil demand of the country. Presently, it is being cultivated in 0.331 million ha area covering fourteen states, whereas the country has potential area of 1.93 million ha for oil palm cultivation spreading in nineteen states ${ }^{2}$. Andhra Pradesh state has 170,000 ha area under oil palm plantation (OPP) of which 70,000 ha area lies in West Godavari district alone.

Oil palm requires relatively higher amount of nutrients for optimum growth and production of fresh fruit bunch (FFB), which is the economic part of the palm. According to Mengel and Kirkby ${ }^{3}$, oil palm needs $162 \mathrm{~kg}$ nitrogen $(\mathrm{N}), 30 \mathrm{~kg}$ phosphorus (P), $217 \mathrm{~kg}$ potassium $(\mathrm{K}), 36 \mathrm{~kg}$ calcium $(\mathrm{Ca})$ and $38 \mathrm{~kg}$ magnesium $(\mathrm{Mg})$, for production of $10 \mathrm{t} \mathrm{FFB/ha/year.} \mathrm{The} \mathrm{FFB} \mathrm{yield} \mathrm{levels} \mathrm{of} \mathrm{OPP} \mathrm{of}$ India vary widely due to various soil-crop management practices adopted by the farmers ${ }^{4}$. But the mean yield to the tune of $15-20 \mathrm{t} \mathrm{FFB/ha/year} \mathrm{is} \mathrm{obtained} \mathrm{in} \mathrm{well-}$ managed plantations. Among the biotic factors, nutrient deficiencies (K, Mg and boron (B)) and $\mathrm{N} / \mathrm{K}$ imbalance in oil palm leaves play important roles in adversely affecting FFB yield in India ${ }^{5,6}$. Best fertilizer management in oil palm through soil and leaf analysis is needed for correcting nutrient disorders and obtaining higher FFB production, as leaf nutrient concentration is directly correlated with FFB yield ${ }^{7}$. Hence, there is need for periodic evaluation of soil properties and leaf nutrient concentration in OPP for effective fertilizer management. The information pertaining to soil fertility status and leaf nutrient concentrations in OPP of the country in general and OPP of Andhra Pradesh state in particular is limited.
For the proper elucidation of leaf nutrient analysis values, Diagnosis and Recommendation Integrated System (DRIS) technique is used as it deals with ratios of nutrient concentration and not the individual nutrient concentration $^{8,9}$. Researchers have used DRIS technique to elucidate leaf nutrient analysis values in many crops like mango (Mangifera indica), apple (Malus pumila), sapota (Manilkara zapota) and guava (Psidium guajava $)^{10-13}$ including oil palm ${ }^{14-16}$. It indicates the order of limiting nutrients so that appropriate corrective measures can be taken up. The information regarding DRIS norms of OPP in different parts of India is scarce. The current study was therefore carried out (i) to estimate soil properties and leaf nutrient status, and (ii) to derive DRIS norms and optimum leaf nutrient ranges in OPP of West Godavari, Andhra Pradesh, India.

The soil and leaf samples were obtained by conducting a survey in OPP of West Godavari, Andhra Pradesh, India situated on $16^{\circ} 07^{\prime} \mathrm{N}$ lat. and $81^{\circ} 01^{\prime} \mathrm{E}$ long. Hot and humid tropical climate prevails in the area. The area receives mean annual rainfall of $950 \mathrm{~mm}$, out of which most rainfall occurs during June to September months. The months of May and December experience the mean highest $\left(39^{\circ} \mathrm{C}\right)$ and the mean lowest $\left(23^{\circ} \mathrm{C}\right)$ temperature respectively. Relative humidity of the area is the highest $(90 \%)$ in July-August months and the lowest $(60 \%)$ in February month. The soils of the area developed from metamorphic, sedimentary, and igneous geological formations, fall under Entisols, Alfisols and Vertisols soil $\operatorname{order}^{17}$. Soil texture varied from sandy clay loam to loamy sand. Oil palm is planted in equilateral triangular design with a spacing of $9 \mathrm{~m} \times 9 \mathrm{~m} \times 9 \mathrm{~m}$ and managed as an irrigated crop in the area.

Altogether 306 soil samples (153 each from 0 to $20 \mathrm{~cm}$ (surface) and 20 to $40 \mathrm{~cm}$ (sub-surface) soil depths) were collected from OPP of West Godavari district. One hundred and fifty three leaf samples were also collected. Soil samples were collected from a point having $1 \mathrm{~m}$ distance from the palm trunk inside $3 \mathrm{~m}$ radius palm basins. The leaf samples were gathered from the 17 th frond of the palm, from where soil samples from the palm basin were collected using the recommended protocol ${ }^{18}$. Air-drying of collected soil samples was carried out in a dust-free environment at ambient temperature. The roots and debris present in dried soil samples were discarded and the samples were ground using pestle and mortar to pass through a sieve of $2 \mathrm{~mm}$ size. After processing, the soil samples were analysed for soil parameters, viz. $\mathrm{pH}^{19}$, electrical conductivity $(\mathrm{EC})^{19}$, organic carbon $(\mathrm{OC})^{20}$, available $\mathrm{P}^{21}$, available $\mathrm{K}^{22}$, exchangeable $\mathrm{Ca}^{23}$, exchangeable $\mathrm{Mg}^{23}$, available $\mathrm{S}^{24}$ and available $\mathrm{B}^{25}$. The collected leaf samples were washed first with tap water followed by $0.2 \%$ detergent solution, $0.1 \mathrm{~N} \mathrm{HCl}$ solution and double-distilled water. The excess water is removed using blotting papers. The washed leaf samples were dried at $70^{\circ} \mathrm{C}$ in an oven for 3 days after air-drying for a while. The dried 
leaf samples were powdered in a stainless steel mill. For estimation of concentration of $\mathrm{P}, \mathrm{K}, \mathrm{Ca}, \mathrm{Mg}$ and $\mathrm{S}$ in processed leaf samples using recommended protocols ${ }^{19}$, the powdered leaf samples were digested using nitric acid-perchloric acid mixture (9:4 ratio). Nitrogen concentration in leaf samples was determined by microKjeldahl method. Azomethine-H method was used for estimation of B concentration ${ }^{26}$.

The descriptive statistical parameters of soil properties and leaf nutrient concentration were obtained. DRIS norms and indices for different nutrients (according to the formulae given below) were obtained (as suggested by Beaufils $^{8}$ and Walworth and Sumner ${ }^{27}$ ) by dividing the whole population into low-yielding and high-yielding groups by considering cut-off FFB yield level of $20 \mathrm{t} / \mathrm{ha}$. For estimation of DRIS norms, the nutrients found deficient in OPP of India were taken into account. The highyielding population reflected the desired condition. The mean nutrient expressions of high-yielding population were considered as diagnostic norms and they formed mean values of sufficiency. The optimum ranges of leaf nutrients were obtained from the mean $\pm 4 / 3$ SD according to Bhargava ${ }^{28}$.

$$
\begin{aligned}
& \text { Index } \mathrm{N}=\frac{[f(\mathrm{~N} / \mathrm{P})+f(\mathrm{~N} / \mathrm{K})+f(\mathrm{~N} / \mathrm{Mg})-f(\mathrm{~B} / \mathrm{N})]}{4}, \\
& \text { Index } \mathrm{P}=\frac{[-f(\mathrm{~N} / \mathrm{P})-f(\mathrm{~K} / \mathrm{P})-f(\mathrm{Mg} / \mathrm{P})-f(\mathrm{~B} / \mathrm{P})]}{4}, \\
& \text { Index } \mathrm{K}=\frac{[-f(\mathrm{~N} / \mathrm{K})+f(\mathrm{~K} / \mathrm{P})+f(\mathrm{~K} / \mathrm{Mg})-f(\mathrm{~B} / \mathrm{K})]}{4}, \\
& \text { Index } \mathrm{Mg}=\frac{[-f(\mathrm{~N} / \mathrm{Mg})+f(\mathrm{Mg} / \mathrm{P})-f(\mathrm{~K} / \mathrm{Mg})-f(\mathrm{~B} / \mathrm{Mg})]}{4}, \\
& \text { Index } \mathrm{B}=\frac{[f(\mathrm{~B} / \mathrm{N})+f(\mathrm{~B} / \mathrm{P})+f(\mathrm{~B} / \mathrm{K})+f(\mathrm{~B} / \mathrm{Mg})]}{4} .
\end{aligned}
$$

Then,

$$
f(\mathrm{~N} / \mathrm{P})=[\{\mathrm{N} / \mathrm{P}) /(\mathrm{n} / \mathrm{p})\}-1] \times(1000 / \mathrm{CV})
$$

where $\mathrm{N} / \mathrm{P}>\mathrm{n} / \mathrm{p}$

$$
f(\mathrm{~N} / \mathrm{P})=[1-\{(\mathrm{n} / \mathrm{p}) /(\mathrm{N} / \mathrm{P})\}] \times(1000 / \mathrm{CV}),
$$

where $\mathrm{N} / \mathrm{P}<\mathrm{n} / \mathrm{p} . \mathrm{N}, \mathrm{P}, \mathrm{K}, \mathrm{Mg}$ and $\mathrm{B}$ indicate nitrogen, phosphorus, potassium, magnesium and boron respectively. Using respective norms and $\mathrm{CVs}$, other functions like $f(\mathrm{~K} / \mathrm{P}), f(\mathrm{~N} / \mathrm{K}), f(\mathrm{~B} / \mathrm{N}), f(\mathrm{~N} / \mathrm{Mg}), f(\mathrm{~K} / \mathrm{Mg}), f(\mathrm{Mg} / \mathrm{P})$, $f(\mathrm{~B} / \mathrm{N}), f(\mathrm{~B} / \mathrm{P}), f(\mathrm{~B} / \mathrm{Mg}), f(\mathrm{~B} / \mathrm{P})$ and $f(\mathrm{~B} / \mathrm{K})$ were also estimated.
Soil $\mathrm{pH}, \mathrm{EC}$ and $\mathrm{OC}$ content ranged from 5.44 to 8.26 (mean 7.35), 0.05 to $0.58 \mathrm{dS} \mathrm{m}^{-1}$ (mean $0.22 \mathrm{dS} \mathrm{m}^{-1}$ ) and 1.17 to $31.2 \mathrm{~g} \mathrm{~kg}^{-1}$ (mean $9.66 \mathrm{~g} \mathrm{~kg}^{-1}$ ) respectively, in 0 to $20 \mathrm{~cm}$ soil depth, and from 5.15 to 8.24 (mean 7.38), 0.05 to $0.78 \mathrm{dS} \mathrm{m}^{-1}$ (mean $0.20 \mathrm{dS} \mathrm{m}^{-1}$ ) and 0.39 to $26.9 \mathrm{~g} \mathrm{~kg}^{-1}$ (mean $5.33 \mathrm{~g} \mathrm{~kg}^{-1}$ ) in 20 to $40 \mathrm{~cm}$ soil depth respectively (Table 1 ). The values of available $\mathrm{P}$ and $\mathrm{K}$ ranged from 29.0 to 1045 and 17.4 to $442 \mathrm{~kg} \mathrm{ha}^{-1}$ respectively in 0 to $20 \mathrm{~cm}$ depth soil and from 27.6 to 998 and 13.3 to $297 \mathrm{~kg} \mathrm{ha}^{-1}$ in 20 to $40 \mathrm{~cm}$ depth soil respectively. The values of exchangeable $\mathrm{Ca}$, exchangeable $\mathrm{Mg}$, available S, and available B spanned from 2.19 to 8.04 meq $100 \mathrm{~g} \mathrm{soil}^{-1}, \quad 0.20$ to $5.70 \mathrm{meq} 100 \mathrm{~g} \mathrm{soil}^{-1}, 9.54$ to $205 \mathrm{mg} \mathrm{kg}^{-1}$ and 0.10 to $22.2 \mathrm{mg} \mathrm{kg}^{-1}$ respectively, in 0 to $20 \mathrm{~cm}$ depth soil and from 2.10 to $7.85 \mathrm{meq} 100 \mathrm{~g} \mathrm{soil}^{-1}$, 0.10 to $5.60 \mathrm{meq} 100 \mathrm{~g} \mathrm{soil}^{-1}, 3.46$ to $181 \mathrm{mg} \mathrm{kg}^{-1}$ and 0.05 to $17.6 \mathrm{mg} \mathrm{kg}^{-1}$ respectively, in 20 to $40 \mathrm{~cm}$ depth. Soil properties had the CV values from $7.13 \%$ to $80.7 \%$ in both the soil layers. The variations in soil properties are predominately attributed to the varied fertilizer application practices along with other cultural practices adopted by plantation managers. This parallels the observation of Behera et al. ${ }^{29}$ who recorded similar values of soil properties in soil layers of OPP in coastal region of western India.

The leaf nutrient concentration varied widely (Table 2). The mean value of leaf nutrient concentration followed the order $\mathrm{N}>\mathrm{Ca}>\mathrm{K}>\mathrm{Mg}>\mathrm{S}>\mathrm{P}>\mathrm{B}$. This corroborates the observation of Lee et al. ${ }^{30}$ who recorded $2.49-2.81 \%$ N, $0.16-0.18 \%$ P, 0.96-1.20\% K, 0.68$1.02 \% \mathrm{Ca}, 0.17-0.26 \% \mathrm{Mg}, 0.14-0.16 \% \mathrm{~S}$ and $13.7-$ $17.3 \mathrm{mg} \mathrm{kg}^{-1} \mathrm{~B}$ in the leaf samples of FELDA clone and FELDA $\mathrm{D} \times \mathrm{P}$ planting material grown in Pahang, Malaysia. Behera et ll. $^{31}$ recorded mean values of leaf nutrient concentration of $2.21-2.49 \% \mathrm{~N}, 0.10-0.53 \% \mathrm{P}$ and $0.56-0.78 \% \mathrm{~K}$, in OPP of different areas of India. The variation in leaf nutrient concentration in the study area is ascribed to differences in soil properties and crop management ways. The CV values for leaf nutrient concentration varied from $23.3 \%$ to $45.8 \%$.

The leaf nutrient $(\mathrm{N}, \mathrm{P}, \mathrm{K}, \mathrm{Mg}$ and $\mathrm{B})$ concentration values were used to derive DRIS norms for the two populations (Table 3). The selected nutrient ratio expressions had higher variance ratio. The DRIS indices for different nutrients were estimated using DRIS norms (Table 4). DRIS indices were found to be 1.21 for $\mathrm{N}, 2.84$ for $\mathrm{P}$, 1.04 for $\mathrm{K},-0.21$ for $\mathrm{Mg}$ and -4.88 for $\mathrm{B}$. It followed the order $\mathrm{B}>\mathrm{Mg}>\mathrm{K}>\mathrm{N}>\mathrm{P}$ which reveals the importance of nutrient requirement in the study area. While devising nutrient management ways in OPP of the area, steps must be undertaken to manage B first. Subsequently, Mg, K, N and $\mathrm{P}$ nutrients need to be managed for obtaining better yield. Behera et al. ${ }^{14,15}$ also recorded nutrient orders of $\mathrm{B}>\mathrm{K}>\mathrm{Mg}>\mathrm{P}>\mathrm{N}$ for Mizoram state and $\mathrm{P}>\mathrm{Mg}>\mathrm{K}>\mathrm{N}>\mathrm{B}$ for west coastal area of India. This variation in nutrient requirement of oil palm plantations 
RESEARCH COMMUNICATIONS

Table 1. Descriptive statistics of soil properties of oil palm plantations of West Godavari, Andhra Pradesh, India $(n=153)$

\begin{tabular}{|c|c|c|c|c|c|c|c|}
\hline Properties & Minimum & Maximum & Mean & SD & $\mathrm{CV}(\%)$ & Skewness & Kurtosis \\
\hline \multicolumn{8}{|l|}{$0-20 \mathrm{~cm}$ depth } \\
\hline $\mathrm{pH}$ & 5.44 & 8.26 & 7.35 & 0.13 & 7.36 & -0.66 & 0.28 \\
\hline $\mathrm{OC}\left(\mathrm{g} \mathrm{kg}^{-1}\right)$ & 1.17 & 31.2 & 9.66 & 5.46 & 56.6 & 1.19 & 1.84 \\
\hline Available-P $\left(\mathrm{kg} \mathrm{ha}^{-1}\right)$ & 29.0 & 1045 & 359 & 279 & 77.6 & 0.93 & -0.28 \\
\hline Available-K $\left(\mathrm{kg} \mathrm{ha}^{-1}\right)$ & 17.4 & 442 & 127 & 80.0 & 62.8 & 1.09 & 1.43 \\
\hline Exchangeable $\mathrm{Mg}$ (meq $100 \mathrm{~g} \mathrm{soil}^{-1}$ ) & 0.20 & 5.70 & 2.15 & 1.07 & 49.9 & 0.54 & -0.12 \\
\hline Available-S $\left(\mathrm{mg} \mathrm{kg}^{-1}\right)$ & 9.54 & 205 & 44.3 & 28.2 & 63.7 & 2.30 & 7.90 \\
\hline Available-B $\left(\mathrm{mg} \mathrm{kg}^{-1}\right)$ & 0.10 & 22.2 & 4.71 & 5.32 & 113 & 1.30 & 0.95 \\
\hline \multicolumn{8}{|l|}{$20-40 \mathrm{~cm}$ depth } \\
\hline $\mathrm{pH}$ & 5.15 & 8.24 & 7.38 & 0.53 & 7.13 & -1.09 & 2.14 \\
\hline $\mathrm{EC}\left(\mathrm{dS} \mathrm{m} \mathrm{m}^{-1}\right)$ & 0.05 & 0.78 & 0.20 & 0.10 & 53.7 & 1.84 & 5.72 \\
\hline $\mathrm{OC}\left(\mathrm{g} \mathrm{kg}^{-1}\right)$ & 0.39 & 26.9 & 5.33 & 3.48 & 65.3 & 2.26 & 10.1 \\
\hline Available-K $\left(\mathrm{kg} \mathrm{ha}^{-1}\right)$ & 13.3 & 297 & 87 & 57.7 & 66.3 & 1.24 & 1.36 \\
\hline Exchangeable Ca (meq $100 \mathrm{~g} \mathrm{soil}^{-1}$ ) & 2.10 & 7.85 & 4.36 & 1.42 & 32.6 & 0.52 & -0.66 \\
\hline Exchangeable $\mathrm{Mg}$ (meq $100 \mathrm{~g} \mathrm{soil}^{-1}$ ) & 0.10 & 5.60 & 2.07 & 1.12 & 54.4 & 0.56 & -0.00 \\
\hline Available-S (mg kg-1) & 3.46 & 181 & 37.7 & 24.8 & 65.7 & 2.38 & 8.94 \\
\hline Available-B $\left(\mathrm{mg} \mathrm{kg}^{-1}\right)$ & 0.05 & 17.6 & 3.90 & 4.41 & 113 & 1.15 & 0.21 \\
\hline
\end{tabular}

$\mathrm{SD}$, Standard deviation; $\mathrm{CV}$, Coefficient of variation.

Table 2. Descriptive statistics of leaf nutrient concentrations for entire population of oil palm plantations of West Godavari, Andhra Pradesh, India $(n=153)$

\begin{tabular}{lcccccrr}
\hline Nutrients & Minimum & Maximum & Mean & SD & CV (\%) & Skewness & Kurtosis \\
\hline N (\%) & 0.62 & 3.97 & 2.34 & 0.57 & 24.3 & 0.18 & 0.39 \\
P (\%) & 0.04 & 0.26 & 0.13 & 0.04 & 27.2 & -0.08 & 0.65 \\
K (\%) & 0.34 & 1.38 & 0.68 & 0.16 & 23.7 & 1.00 & 1.71 \\
Ca (\%) & 0.66 & 2.66 & 1.41 & 0.33 & 23.3 & 0.37 & 0.53 \\
Mg (\%) & 0.10 & 1.03 & 0.51 & 0.18 & 35.7 & 0.29 & -0.22 \\
S (\%) & 0.02 & 0.35 & 0.17 & 0.05 & 29.0 & 0.37 & 1.52 \\
B (mg kg $\left.{ }^{-1}\right)$ & 9.55 & 119 & 48.7 & 22.3 & 45.8 & 0.72 & -0.04 \\
\hline
\end{tabular}

$\mathrm{SD}$, Standard deviation; CV, Coefficient of variation.

Table 3. Leaf nutrient norms of oil palm plantations of West Godavari, Andhra Pradesh, India

\begin{tabular}{|c|c|c|c|c|c|c|c|c|c|}
\hline \multirow[b]{2}{*}{ Nutrient expressions } & \multicolumn{4}{|c|}{ Low yielding population } & \multicolumn{4}{|c|}{ High yielding population } & \multirow[b]{2}{*}{$\mathrm{Sa} / \mathrm{Sb}$} \\
\hline & Mean & Variance (Sa) & SD & $\mathrm{CV}$ & Mean & Variance $(\mathrm{Sb})$ & SD & $\mathrm{CV}$ & \\
\hline $\mathrm{N}$ & 2.08 & 0.13 & 0.36 & 17.6 & 2.10 & 0.16 & 0.40 & 19.1 & 0.81 \\
\hline$P$ & 0.13 & 0.00 & 0.03 & 25.6 & 0.12 & 0.00 & 0.03 & 27.0 & 0.96 \\
\hline $\mathrm{K}$ & 0.67 & 0.02 & 0.13 & 19.2 & 0.68 & 0.02 & 0.15 & 21.5 & 0.76 \\
\hline $\mathrm{Mg}$ & 0.47 & 0.04 & 0.19 & 40.3 & 0.48 & 0.03 & 0.17 & 36.4 & 1.33 \\
\hline $\mathrm{B}$ & 33.2 & 177 & 13.3 & 40.1 & 41.4 & 199 & 14.1 & 34.1 & 0.89 \\
\hline $\mathrm{N} / \mathrm{P}$ & 17.4 & 33.9 & 5.82 & 33.5 & 18.9 & 80.9 & 8.99 & 47.5 & 0.42 \\
\hline $\mathrm{N} / \mathrm{K}$ & 3.22 & 0.65 & 0.80 & 25.0 & 3.19 & 0.69 & 0.83 & 25.9 & 0.94 \\
\hline $\mathrm{N} / \mathrm{Mg}$ & 5.32 & 8.09 & 2.84 & 53.4 & 5.10 & 6.68 & 2.58 & 50.7 & 1.21 \\
\hline $\mathrm{B} / \mathrm{N}$ & 16.9 & 70.2 & 8.37 & 49.6 & 20.6 & 68.9 & 8.30 & 40.3 & 1.02 \\
\hline $\mathrm{K} / \mathrm{P}$ & 5.57 & 3.70 & 1.92 & 34.5 & 6.10 & 7.40 & 2.72 & 44.6 & 0.50 \\
\hline $\mathrm{Mg} / \mathrm{P}$ & 3.96 & 4.72 & 2.17 & 54.8 & 4.30 & 5.35 & 2.31 & 53.8 & 0.88 \\
\hline $\mathrm{B} / \mathrm{P}$ & 286 & 23394 & 153 & 53.5 & 368 & 32736 & 181 & 49.2 & 0.71 \\
\hline $\mathrm{K} / \mathrm{Mg}$ & 1.77 & 1.15 & 1.07 & 60.5 & 1.66 & 0.76 & 0.87 & 52.3 & 1.51 \\
\hline $\mathrm{B} / \mathrm{K}$ & 52.0 & 660 & 25.7 & 49.4 & 63.6 & 650 & 25.5 & 40.3 & 1.02 \\
\hline $\mathrm{B} / \mathrm{Mg}$ & 86.1 & 2821 & 53.1 & 61.7 & 99.3 & 2829 & 53.2 & 53.6 & 1.00 \\
\hline
\end{tabular}

$\mathrm{SD}$, Standard deviation; CV, Coefficient of variation. 


\section{RESEARCH COMMUNICATIONS}

Table 4. DRIS indices for nutrients of oil palm plantations of West Godavari, Andhra Pradesh, India

\begin{tabular}{lc}
\hline Nutrients & Indices \\
\hline $\mathrm{N}$ & 1.21 \\
$\mathrm{P}$ & 2.84 \\
$\mathrm{~K}$ & 1.04 \\
$\mathrm{Mg}$ & -0.21 \\
$\mathrm{~B}$ & -4.88 \\
\hline
\end{tabular}

Table 5. Optimum leaf nutrient ranges of oil palm plantations of West Godavari, Andhra Pradesh, India

\begin{tabular}{lc}
\hline Nutrients & Optimum concentration \\
\hline $\mathrm{N}(\%)$ & 1.57 to 2.63 \\
$\mathrm{P}(\%)$ & 0.08 to 0.16 \\
$\mathrm{~K}(\%)$ & 0.48 to 0.88 \\
$\mathrm{Mg}(\%)$ & 0.25 to 0.71 \\
$\mathrm{~B}\left(\mathrm{mg} \mathrm{kg}^{-1}\right)$ & 22.6 to 60.2 \\
\hline
\end{tabular}

in different parts of the country is because of differences in climatic conditions, soils and crop management ways. Optimum leaf nutrient ranges for the study area were estimated by considering mean leaf nutrient concentration values of high-yielding group. It was $1.57-2.63 \%$ for $\mathrm{N}$, $0.08-0.16 \%$ for $\mathrm{P}, 0.48-0.88 \%$ for $\mathrm{K}, 0.25-0.71 \%$ for $\mathrm{Mg}$ and $22.6-60.2 \mathrm{mg} \mathrm{kg}^{-1}$ for B (Table 5). Optimum leaf nutrient range indicates that palms having optimum leaf nutrient concentration produce satisfactory yield and there is no need to make changes in fertilizer schedule.

Estimation of soil properties and leaf nutrient concentration of OPP and derivation of DRIS norms and indices could help in understanding the nutritional status of the plantations, which varies from area to area depending upon soils, climatic conditions and crop management ways. It was found that the order of requirement of nutrients in OPP of west Godavari district is $\mathrm{B}>\mathrm{Mg}>$ $\mathrm{K}>\mathrm{N}>\mathrm{P}$. The optimum concentrations of leaf nutrients were $1.57-2.63 \%$ for $\mathrm{N}, 0.08-0.16 \%$ for $\mathrm{P}, 0.48-0.88 \%$ for $\mathrm{K}, 0.25-0.71 \%$ for $\mathrm{Mg}$ and $22.6-60.2 \mathrm{mg} \mathrm{kg}^{-1}$ for $\mathrm{B}$. Based on this information, better ways of nutrient management can be formulated for obtaining improved yield in OPP.

1. Anon, World palm oil production 2016/2017, 2017; www. worldpalmoilproduction.com/default.asp (accessed on 12 May 2017).

2. Rethinam, P., Arulraj, S. and Rao, B. N., Assessment of additional potential areas for oil palm cultivation in India. Report submitted to Department of Agriculture and Cooperation, Ministry of Agriculture, Govt of India. Directorate of Oil Palm Research, Pedavegi, Andhra Pradesh, 2012, pp. 1-84.

3. Mengel, K. and Kirkby, E. A., Principles of Plant Nutrition, International Potash Institute, Basel, Switzerland, 1987.

4. Prasad, M. V., Sarkar, A. and Jameema, J., Performance of oil palm production technologies. Indian Res. J. Ext. Edn., 2013, 10, $10-15$.
5. Suresh, K., Mathur, R. K. and Behera, S. K., Oil palm. In Abiotic Stress Physiology of Horticultural Crops (eds Rao, N. et al.), Springer India, 2016, pp. 333-342.

6. Behera, S. K., Rao, B. N. and Suresh, K., Soil health management in oil palm. In Soil Health Management in Plantation Crops (eds Maheswarappa, H. P. and Chowdappa, P.), Today \& Tomorrow's Publishers, New Delhi, India, 2017, pp. 115-144.

7. Goh, K. J., Hardter, R. and Fairhust, T. H., Fertilizer for maximum return. In Oil Palm: Management for High and Sustainable Yields (eds Fairhust, T. H. and Hardter, R.), International Potash Institute, Singapore, 2003, pp. 279-306.

8. Beaufils, E. R., Diagnosis and recommendation integrated system (DRIS): a general scheme for experimentation and calibration based on principals developed from research in plant nutrition. Univ. Natal. Soil Sci. Bull., 1973, 1, 1-132.

9. Sumner, M. E., Interpretation of nutrient ratios in plant tissues. Commun. Soil Sci. Plant Anal., 1978, 9, 335-345.

10. Pimolaskar, M. and Bhargava, B. S., Leaf and soil nutrient norms in mango (Mangifera indica L.) grown in tribal belt of southern Gujarat. J. Indian Soc. Soil Sci., 2003, 51, 268-272.

11. Nachtigall, G. R. and Dechen, A. R., DRIS use on apple orchard nutritional evaluation in response to potassium fertilization. Commun. Soil Sci. Plant Anal., 2007, 38, 2557-2566.

12. Savita, B. and Anjaneyulu, K., Development of leaf nutrient norms and identification of yield limiting nutrients using DRIS in sapota cv. Kalipatti. J. Hortic. Sci., 2008, 3(2), 136-140.

13. Hundal, H. S., Singh, D. and Singh, K., Monitoring nutrient status of guava fruit trees in Punjab, northwest India through diagnostic and recommendation integrated system approach. Commun. Soil Sci. Plant Anal., 2007, 38, 2117-2130.

14. Behera, S. K., Suresh, K., Rao, B. N., Manoja, K. and Manorama, K., Soil nutrient status and leaf nutrient norms in oil palm (Elaeis guineensis Jacq.) plantations grown on west coastal area of India. Commun. Soil Sci. Plant Anal., 2016, 47(2), 255-262.

15. Behera, S. K., Suresh, K., Rao, B. N., Ramachandrudu, K., Manorama, K. and Harinarayana, P., Soil fertility and yield limiting nutrients in oil palm plantations of north-eastern state Mizoram of India. J. Plant Nutr., 2017, 40(8), 1165-1171.

16. Matos, G. S. B., Fernandes, A. R., Wadt, P. G. S., Pina, A. J. A., Franzini, V. I. and Ramos, H. M. N., The use of DRIS for nutritional diagnosis in oil palm in the state of Pará. Revista Brasileira de Ciencia do Solo., 2017, 41, e0150466; doi:10.1590/ $18069657 \mathrm{rbcs} 20150466$.

17. Soil Survey Staff, Keys to Soil Taxonomy. USDA-Natural Resources Conservation Service, Washington, DC, 2014, 12 th edn.

18. Behera, S. K. and Suresh, K., Soil and leaf sampling in oil palm. In Compendium of Lectures on Soil and Leaf Nutrient Analysis in Oil Palm (eds Prasad, M. V., Behera, S. K. and Mounika, B.), Directorate of Oil Palm Research, Pedavegi, India, 2013, pp. 14-19.

19. Jackson, M. L., Soil Chemical Analysis, Prentice Hall of India, Indian edn., New Delhi, 1973.

20. Walkley, A. J. and Black, I. A., An examination of the Degtjareff method for determining soil organic matter and a proposed modification of the chromic acid titration method. Soil Sci., 1934, 37, 29-38.

21. Olsen, S. R., Cole, C. V., Watanable, F. S. and Dean, L. A., Estimation of available phosphorous in soils by extraction with sodium bicarbonate. Circular of United States Department of Agriculture No. 939, 1954.

22. Hanway, J. J. and Heidel, H., Soil analyses methods as used in Iowa state college soil testing laboratory. Iowa Agric., 1952, 57, $1-31$.

23. Jones Jr, J. B., Soil test methods: past, present, and future. Commun. Soil Sci. Plant Anal., 1998, 29, 1543-1552.

24. Williams, C. H. and Steinbergs, A., Soil sulphur fractions as chemical indices of available sulphur in some Australian soils. Aust. J. Agric. Res., 1969, 10, 340-352. 
25. Gupta, U. C., A simplified method for determining hot-water soluble boron in podzol soils. Soil Sci., 1967, 103, 424-428.

26. Gaines, T. P. and Mitchell, G. A., Boron determination in plant tissue by the azomethine-H method. Commun. Soil Sci. Plant Anal., 1979, 10, 1099-1108.

27. Walworth, J. L. and Sumner, M. E., The diagnosis and recommendation integrated system (DRIS). Adv. Soil Sci., 1987, 6, 149-188.

28. Bhargava, B. S., Leaf analysis for nutrient diagnosis, recommendation and management in fruit crops. J. Indian Soc. Soil Sci., 2002, 50, 352-373.

29. Behera, S. K. et al., Spatial variability of some soil properties varies in oil palm (Elaeis guineensis Jacq.) plantations of west coastal area of India. Solid Earth, 2016, 7, 979-993.

30. Lee, C. T., Rahman, Z. A., Musa, M. H., Norizan, M. S. and Tan, C. C., Leaf nutrient concentrations in oil palm as affected by genotypes, irrigation and terrain. J. Oil Palm Environ., 2011, 2, $38-47$.

31. Behera, S. K., Suresh, K., Ramachandrudu, K., Manorama, K. and Rao, B. N., Mapping spatial variability of leaf nutrient status of oil palm (Elaeis guineensis Jacq.) plantations in India. Crop Pasture Sci., 2016, 67(1), 109-116; doi: 10.1071/CP15029.

Received 9 November 2018; accepted 20 May 2019

\section{Crustal depth estimation over the Indian lithospheric plate using satellite geoid and a gravimetric-isostatic model}

\section{T. J. Majumdar* \\ Space Applications Centre (ISRO), Ahmedabad 380 015, India}

\begin{abstract}
Moho depth or simply, Moho, in general, describes the boundary between the earth's crust and the mantle and is a very important geophysical parameter. It is also related to the earth's crustal thickness at any point. Geoid and gravity anomalies derived from satellite altimetry are gradually gaining importance in marine geo-scientific investigations. However, satellite gravity technique is not working over land/continent. So, we need to develop technique like the VMM model which is equally working over land. In addition of generating crustal thickness, it also saves energy to generate Bouguer anomaly over land and ocean.
\end{abstract}

Keywords: Crustal depth, geoid, gravity anomaly, lithospheric plate, satellite altimetry

THE Mohorovičić discontinuity or Moho is one of the most important geophysical parameters for defining the

*e-mail: tapan.j.majumdar@gmail.com subsurface crustal thickness. It also defines the boundary between the earth's crust and mantle. Gravity field models (mostly via satellites) are being used for a variety of geophysical and oceanographic explorations. Surface gravity data also generate the gravity field, but acquiring data uniformly over the earth is difficult and timeconsuming. Since the sea surface largely conforms to the geoid, satellite altimetry provides precise measurements of the marine gravity field, provided that proper corrections are made to altimeter data and other relevant errors ${ }^{1}$.

Now-a-days, it is possible to generate large-scale altimeter-derived residual/prospecting geoid and gravity anomaly maps over the oceans. They are used to infer subsurface geological structures analogous to gravity anomaly maps generated through ship-borne surveys. Geoid is generated by the equipotential surface over the oceans $^{2-4}$, which contains information regarding mass distribution inside the entire earth. Geoid is then converted to gravity using a simple technique ${ }^{4,5}$. Gravity anomaly maps provide information on the subsurface density distribution, major tectonic and structural lineaments, geodynamic aspects of a plate margin and structure of the crust and lithosphere ${ }^{6}$. However, satellite gravity technique cannot be used over land/continent. So, we need to develop a technique like the Vening MeineszMoritz (VMM) model which works equally well over land for generating crustal thickness ${ }^{7}$. It also helps generate Bouguer anomaly over land and ocean.

An improved spherical harmonic model of the earth's gravitational potential up to degree and order 360 has been generated by NASA, NIMA and OSU (USA) ${ }^{8}$. The Earth Gravitational Model 1996 (EGM96) incorporates improved surface gravity data. A very high-resolution geoid (spatial resolution as high as $\sim 4 \mathrm{~km}$ ) and gravity anomalies have been generated from ERS-1, Seasat, GeosatGeodetic Mission (GGM) and TOPEX/POSEIDON data $^{4,8}$. The Bouguer gravity map brings out the following striking features ${ }^{9-11}$ : (i) Dominance of negative Bouguer anomalies over a major part of the Indian subcontinent, reaching a maximum value of $380 \mathrm{mGal}$ over the Himalayas. (ii) Belts of positive Bouguer anomalies are seen along the west coast. Positive anomaly trends characterize part of the east coast and the Shillong plateau. (iii) The trends of anomalies are parallel to the major structural trend: NNW-SSE Dharwar trend in South India, NE-SW Aravalli trend and the Himalayan trend ${ }^{9-11}$. (iv) Several gravity highs and lows can also be identified. Figure 1 shows the residual geoid anomaly map generated using high-resolution altimeter data over oceans surrounding Indian peninsula. The bathymetric and tectonic features as observed in the residual geoid image are given elsewhere ${ }^{3,4}$. They provide important information on the structure of the compensated lithosphere.

The Bouguer anomaly map of India has also been digitized and the values interpolated at $10 \mathrm{~km}$ interval to 